\title{
Value Added Agriculture: Is It Right for Me?1
}

\section{Edward Evans ${ }^{2}$}

\section{Introduction}

In response to declining net farm income in a fiercely competitive global market, many agricultural producers are being advised to engage in value added activities to survive. While such an approach may offer opportunities to increase net farm income, starting any new enterprise can be risky, so a careful assessment must be made to determine if a particular type of enterprise is suitable for a particular producer.

The purpose of this article is to explore the concept of value added agricultural businesses and to provide a set of preliminary questions which may help agricultural producers decide whether a particular value added business is suitable for them.

\section{Value Added Agricultural Businesses}

According to Amanor-Boadu (2003), an initiative qualifies as value-adding if it satisfies either of two conditions: (1) if one is rewarded for performing an activity that traditionally has been performed at another stage farther down the supply chain, or (2) if one is rewarded for performing an activity that has never been performed in the supply chain. In the first situation, producers might bypass processors by processing their own production, or producers might bypass wholesalers by selling directly to consumers (direct marketing).

In the second situation, agricultural producers might be able to command higher prices for commodities by adapting new varieties that yield a more uniform commodity, thus reducing the need for sorting at the processing level. Since the processor no longer has to incur this cost, a portion of the savings could be passed on to the grower in the form of higher commodity prices. Another example would be the transformation of a basic agricultural commodity into a processed product desired by consumers.

Value added agricultural business can also be defined as any activity an agricultural producer performs outside of traditional commodity production to receive a higher return per unit of commodity sold. This includes activities such as agritourism and entertainment agriculture.

This wider definition has several implications. First, it implies that a value added initiative qualifies if the net return per unit of the commodity sold increases. A case in point is where an agricultural producer provides farm tours (agritourism) as a means of increasing net farm income. Even if the

1. This is EDIS document FE638, a publication of the Food and Resource Economics Department, Florida Cooperative Extension Service, Institute of Food and Agricultural Sciences, University of Florida, Gainesville, FL. Published May 2006. Please visit the EDIS website at http://edis.ifas.ufl.edu.

2. Edward Evans, Assistant Professor, Food and Resource Economics Department, Tropical Research and Education Center, Homestead, FL, Florida Cooperative Extension Service, Institute of Food and Agricultural Sciences, University of Florida, Gainesville, FL.

The Institute of Food and Agricultural Sciences (IFAS) is an Equal Opportunity Institution authorized to provide research, educational information and other services only to individuals and institutions that function with non-discrimination with respect to race, creed, color, religion, age, disability, sex, sexual orientation, marital status, national origin, political opinions or affiliations. U.S. Department of Agriculture, Cooperative Extension Service, University of Florida, IFAS, Florida A. \& M. University Cooperative Extension Program, and Boards of County Commissioners Cooperating. Larry Arrington, Dean 
price of the commodity remains the same, as long as the overall net income increases, the initiative is considered to be value added. Second, an activity is only considered to be value added if someone is willing to pay for it. Hence, at the end of the day, the costs incurred for carrying out the activity should be less than the benefits received. Third, while such activities are aimed at increasing net returns to the farm business, they do not necessarily imply a reduction in the levels of risk faced by the producers. In fact, they often increase the level of risk exposure since, by definition, they imply undertaking activities not traditionally performed by the producers. This implies the need to acquire additional skills where needed and to adopt risk management tools to minimize the level of risk as much as possible. There are several factors driving this trend. In this article, attention is given to situations faced by agricultural producers in Miami-Dade County, Florida.

\section{Factors Driving the Need to Engage in Value Added Agricultural Businesses}

As stated earlier, the need to become engaged in value added activity reflects the need to shore up farm income which has been declining in recent years. Figure 1 shows the trends for the inflation-adjusted average farm production expenses and average net cash farm income for agricultural producers in Miami-Dade County, Florida over the period 1987 to 2002 (Census of Agriculture). The data clearly indicate that while production expenses exhibit an upward trend over the entire period, net farm income has been decreasing since 1997 . While several factors contribute to the downward trend, the major impact has been trade liberalization, which has depressed primary agricultural commodity prices while having little or no effect on production costs.

In addition to the above situation in which net incomes have been pressured from both sides, there has been a noticeably widening farm-retail price spread (the difference between the prices the agricultural producers receive and the retail prices consumers pay). While the declining share of the consumer food dollar going to the agricultural producers is not a new phenomenon, it has become more striking within recent years, reflecting

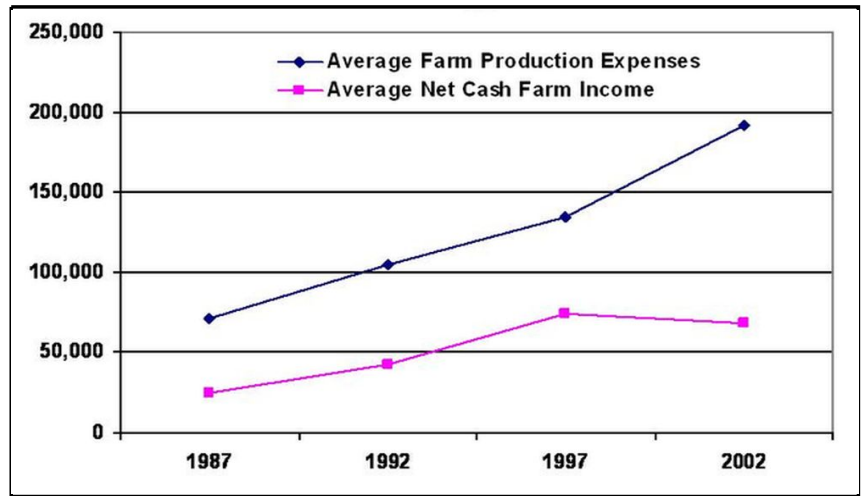

Figure 1. Average farm production expenses and income for Miami-Dade County, Florida, 1987-2002 (dollars)

consumer demand for off-farm marketing services. In other words, as consumer demand for more and more marketing services in the form of convenience and ready-to-eat food increases, the farm-retail price spread increases and the agricultural producer share decreases. In general, the more commodities are processed off-farm before reaching the retail level, the smaller will be the farm share. This can clearly be seen in the comparison made between the farm-retail spread of fresh orange juice (requires a fair amount of processing) and that of fresh oranges (does not require much processing). It therefore seems logical that one way agricultural producers might enhance their income and increase their share of the consumer dollar is by tapping into some of the marketing activity (direct sales, processing, packaging, etc.). As noted earlier, this makes perfect sense; however, it is important that agricultural producers are aware of some of the potential pitfalls.

\section{Examples of Value Added Businesses in the Miami-Dade Area}

Examples of value added business operations of some agricultural producers in the Miami-Dade area include:

- Wineries using tropical fruits.

- Tropical fruit ice cream and milk shakes.

- Jams and jellies.

- Fruit baskets.

- Bed and Breakfasts. 
- Agritourism (e.g., farm tours, festivals, picnics, catered parties).

- Bird watching.

- Fishing.

- Spice parks.

- Alligator farms.

- Direct sales to restaurants and retailers.

- Farmers markets.

- U-pick, or pick-your-own.

- Roadside markets.

\section{Issues for Consideration}

When considering embarking on value added agricultural initiative, it important for the producer to spend time on planning before committing resources. For starters, a producer might consider the following preliminary questions:

1. Can I describe the nature of the value added initiative in plain and simple language? [The easier it is for you to describe what you have in mind, the better grasp you will have of what you want to do.]

2. Will anybody want what I intend to offer and be willing to pay for it? [Before answering this question, you might need to do some scouting for yourself without giving the idea away if it is a new one. Remember that it does not matter who pays as long as somebody will.]

3. Is the potential payoff big relative to its costs?

[As discussed earlier, an initiative is only considered to add value if it covers more than the costs, so as to make it worthwhile. Furthermore, the whole reason of undertaking this initiative is to improve the overall farm income.]

4. Does the initiative have staying power and the potential to grow? [Depending on the level of financial commitment needed, it is important, even at this stage, to assess whether the initiative contemplated has the potential to be sustainable or is just a fad.]
5. Do I have the required resources or access to them?

6 . Is this something I will enjoy doing?

7. Can I cope with the downside if things do not turn out the way they should?

If the answer to all seven questions is "yes", then proceed to the second step, which is preparing a written business plan. In brief, writing a business plan helps demonstrate that you have fully researched the proposed value added initiative, that you know what to do, and that you can manage the financial risks.

\section{Concluding Remarks}

In today's global economy characterized by fierce competition, it is becoming extremely difficult for agricultural producers to focus solely on producing primary commodities and still expect to realize a decent standard of living. Adding value to agriculture is a logical way to stem the decline in farm income. There are many ways to add value to agriculture products - a few have been mentioned in this article. However, while such initiatives are capable of solving some of the farm financial ills and should be encouraged, there still are pitfalls that could worsen an already bad situation. Consequently, before embarking on such initiatives, agricultural producers should make sure they have carried out careful assessments of the alternatives and that the alternatives are well within their risk tolerance (the amount of downside a business or a person can comfortably assume).

\section{References}

Amanor-Boadu, Vincent. 2003. Preparing for Agricultural Value-Adding Business Initiatives: First Things First. Department of Agricultural Economics Agricultural Marketing Resource Center, Kansas State University, Manhattan, KS. http://www.agecon.k-state.edu/accc/kcdc/ PDF\%20Files/Preparation\%20Steps.pdf.

Census of Agriculture. Various issues. U.S. Census of Agriculture, United States Department of Agriculture, Washington, D.C. 